International Journal of English Literature and Social Sciences
Vol-6, Issue-2; Mar-Apr, 2021
Journal Home Page Available: https://ijels.com/
Journal DOI: $10.22161 /$ ijels

\title{
Inspiring future entrepreneurs: The effect of experiential learning on the entrepreneurial intention at higher education
}

\author{
Govand Anwar, Nabaz Nawzad Abdullah
}

Department of Business Administration, College of Administration and Financial Sciences, Knowledge University, 44001 Erbil, Kurdistan Region, Iraq

Received: 03 Dec 2020; Received in revised form: 14 Feb 2021; Accepted: 09 Mar 2021; Available online: 31 Mar 2021 (C)2021 The Author(s). Published by Infogain Publication. This is an open access article under the CC BY license (https://creativecommons.org/licenses/by/4.0/).

\begin{abstract}
The purpose of this study is to measure the influence of experiential learning on the entrepreneurial intention at higher education. To enable the research to measure experiential learning, the researchers used three dimensions as independent factors (empirical learning, Cognitive loading, and Selfefficacy) and on the other hand entrepreneurial intention at higher education as dependent factor. The study was carried out at private universities in Erbil. The researchers employed quantitative research method via adapting questionnaire from academic source and publish it online to gather information from participants. The questionnaire was distributed randomly among 120 academic and administrative staffs of private universities. The participants of the present study were 103 participants from different private universities in Kurdistan region of Iraq. The study developed three research hypotheses, the findings revealed that, as for the first research hypothesis found that an empirical Learning strongly predicts entrepreneurial intention, implying that empirical Learning would have a clear beneficial relationship with entrepreneurial intention. As for the second research hypothesis, it was found that a cognitive loading strongly predicts entrepreneurial intention, implying that cognitive loading would have a clear beneficial relationship with entrepreneurial intention, and lastly as for the third research hypothesis, it was found that self-efficacystrongly predicts entrepreneurial intention, implying that Floatationwould have a clear beneficial relationship with entrepreneurial intention.
\end{abstract}

Keywords- Experiential Learning, Empirical Learning, Cognitive Loading, Self-Efficacy, Entrepreneurial Intention.

\section{INTRODUCTION}

Entrepreneurship has been celebrated as a catalyst of revolution in the outlook of the new world economy (Khan \& Abdullah, 2019). Challenges in work security due to strong competition (Mueller, 2011) and job insecurity (Sukavejworakit et al. 2018) have led developing and industrialized nations to pursue entrepreneurship in order to achieve fiscal development and personal objectives (Anwar, 2017). Intrinsically, entrepreneurship is seen as a vital element in order to level competition in a competitive market environment and enhance economic well-being for nations. As a result of this attention, academic researchers have increased their research efforts on entrepreneurship, in particular their contributions and significance (Ozaralli \& Rivenburgh, 2016). Lately, amid the opposition of the coalition of developing countries, Malaysia has seen a decline in the total number of entrepreneurships produced. Despite a range of government-initiated schemes encouraging entrepreneurship and instilling a sense of entrepreneurship among young people and young adults, there has been a stalemate in the founding of new companies and a low number of new business developments. In comparison, entrepreneurial schooling in the nation is considered to be inadequate in influencing students on the road to entrepreneurship and entrepreneurship (Sukavejworakit et al. 2018). This is confirmed by the results of Aries et al. (2020), who found that just $45 \%$ of all 
university graduates of entrepreneurship studied were entrepreneurs following completion of their studies. Motivational perspective is a crucial factor that should be explored in order to explain the tendency of university graduates to be unable to pursue careers in entrepreneurship (Prabhu et al. 2020). Notwithstanding the results of many studies suggesting a favorable relationship between entrepreneurship education and entrepreneurship, several studies such as Anwar, (2016) supported by Tan et al. (2020) argued that entrepreneurship education is unenthusiastic. Abdullah et al. (2017) have argued that while there is some evidence that entrepreneurship education plays a positive role in student entrepreneurship, the influence of university entrepreneurship education has been debated in particular as to the effect on students' transition to graduate entrepreneurship. It is important to note that experiential Learning in Entrepreneurship Education stimulates students' ability to see socio-economic challenges as an obstacle. This may lead them to articulate entrepreneurial behavior as a reaction to the socio-economic problem found (Bell \& Bell, 2020). This is especially significant because the expression of the entrepreneurial purpose of university students confirms that they are ready for a future in entrepreneurship. To this end, this research suggests that the presentation of entrepreneurial intent by university students, inspired by successful experiential learning, increases the tendency of postgraduates to participate in entrepreneurship even after graduation (Othman \& Abdullah, 2016). The key problem here is that the presentation of entrepreneurial purpose by university students should be the primary objective of the university entrepreneurship curriculum, so that experiential learning in entrepreneurship education can help move forward and accomplish this aim (Anwar, 2017). Universities are known to be incubators of entrepreneurship projects of every Thus, the focus of society must be on the adoption of experiential learning methods in order to promote a common perspective on the communication of entrepreneurial purpose by graduates (Youssef et al. 2021). As a result, studies such as Abdullah \& Abdul Rahman, (2015) on educational entrepreneurship in university education have suggested the creation of demanding learning experiences to inspire entrepreneurship. Creation of innovative problem-solving skills to enhance students " Entrepreneurship plans. However, taking into account the pivotal role of experiential learning in promoting the entrepreneurial growth of university students, there is one factor. The degree to which it is experiential is of great importance that many researchers have overlooked. Learning motivates university students to demonstrate an entrepreneurial goal in the service of an entrepreneurial future in graduation (Qazi et al. 2020).

\section{LITERATURE REVIEW}

\section{Experiential Learning}

Many scholars claim that the principle of experiential learning (EL) has been around for at least Dewey's work (Hameed \& Anwar, 2018) conclude that, according to some descriptions, EL's existence dates back only to the T-groups of the 1950s and 1960s. In any case, EL and its various derivatives and variants continue to be a subject of much study and relevance to this dissertation. The participants in this study are students, instructors, administrators and industry partners of two schools whose programs can be described as experiential in nature. Anwar \& Ghafoor, (2017), stated that not all students can find the EL methodologies they need. When EL makes use of peer reviews, some students feel that the mechanism is stressful, both getting criticism of others and getting negative feedback about their own opinions and suggestions may be unsettling. Similar anxiety was observed in the setting up of the working groups. Students were not sure how to treat the members of the party who did not complete their activities. This dissatisfaction was felt by both performing and nonperforming students. While significant in both conventional and EL settings, the perception of a positive atmosphere is much more critical in the EL environment. Prabhu et al. (2019) stated that, "If students perceive the atmosphere as unsupportive (for example, "This teacher seems aggressive to women in engineering"), they will threaten perceptions of achievement and undermine motivation" (Tierno et al. 2020). Because EL continues to have a larger range of characters who can affect the community, colleagues, teachers, managers, and future outside collaborators, it is important that we track for a constructive, inclusive environment. Students are not the only ones required to transform the world of EL. Teachers may also have a particular position to play. The position of the source of information shall be replaced by a tutor or facilitator. Bazan et al. (2020) stated this metamorphosis rather eloquently, On the opposite, this modern model poses far more obstacles to school administrators and teachers because their primary roles have changed from instilling prescribed material in students through well-established standardized processes to creating an instructional atmosphere that gives children the ability to live a positive and engaging educational life. (Anwar \& Qadir, 2017). Questions often occur in relation to the mastery demonstration method. Adjustments to the learning process are likely to have to be made to reflect local, state and federal requirements; these modifications are outside the reach of this article. Teachers will obviously be stressed in the EL environment; some will find it very rewarding and satisfying, while others will feel disenchanted enough to abandon the EL program (Anjum et al. 2020). 


\section{Entrepreneurial Intention}

EI is also understood as human attitudes toward the consequences of consequential decisions and their desirability of belief, self-efficacy, and probability of responding to opportunities (Yi, 2020). This takes into account ambition, unwavering commitment and the desire to be self-reliant. Although these traits are widely recognized as habits, a broad body of research in EI literature has mostly studied behaviors that influence motive. Despite being recognized as a widely-researched field (Anwar \& Shukur, 2015), other researchers argue that there is still a shortage of literature findings in the EI, especially in developing countries that cover issues facing entrepreneurship practices that have yet to be clarified (Anwar \& Surarchith, 2015). To a large degree, the essential role assumed by the EI in the implementation of entrepreneurship efforts has been investigated (Abdullah \& Othman, 2019). Researchers also use socio-psychological constructs to examine the EI and to investigate related behaviors and determinants (Prabhu et al. 2020). These models have been shown to be powerful in explaining the interaction between personality variables and the EI. In addition, these models are used to analyze expected and deliberate actions in entrepreneurship (Anwar \& Abd Zebari, 2015). Gaining an awareness of the EI is also undeniably important, since the purpose forms the center for individuals to embark on an entrepreneurial path and contribute to the realization of business projects (Dijinira et al. 2020). Literature on EI mostly employed tertiary-level students as subjects of study (Abdullah \& Othman, 2016). A survey of Norwegian business students found that three TPB variables had a substantial impact on the EI (Dijinira et al. 2020).

Many of the research cited below ties those learning experiences to the enhancement of entrepreneurial purpose. This linkage may be achieved by developing an understanding of what entrepreneurs are doing, which may lead to an increase in perceived viability or an understanding of the advantages of entrepreneurship, which may lead to an increase in the impact of social expectations and perceived desirability. One way to develop this kind of awareness is through the use of effective advisors and champions, teachers as an example. However, Zulfiqar et al. (2021), described another approach, and even better are growth experiences that include resources for mastering of these competencies (Fayolle et al. 2020). Exposure of diverse life and work environments broadens the scope of what they see as possible. This behavioral modeling will work either vicariously using reputable consultants or directly by providing participants with hands-on experience in secure environments (Naz et al. 2020). Again, literature confirms the possibility that openness to an entrepreneurial phase could have an effect on expectations of viability, desirability or both. Khan \& Abdullah, (2019) address the capacity of education to alter profound conceptual models that may lead people to see more possibilities or to see themselves as entrepreneurs. While Mueller, (2011) reminded us in their earlier work that, "Teaching people about the realities of entrepreneurship may increase their entrepreneurial self-efficacy, but at the same time reduce the perceived desirability of starting a company" (Sukavejworakit et al. 2018). Demonstrating students the obstacles and dangers of starting a company may deter others from following an entrepreneurial lifestyle, but learning this will allow learners to think about proper awareness mechanisms (Anwar, 2017). The previous segment concentrated on experiential and project-based learning as a tool for providing students with exposure to a broad range of opportunities, some of which could help develop their entrepreneurial intentions (Ozaralli \& Rivenburgh, 2016). Conventionally, Entrepreneurship Education (EE) has been characterized as an education that provides appropriate skills for the establishment of a new enterprise. Despite this, the optimal mode of distribution has been widely debated in the literature. A number of methods exist to deliver EE, based on various goals (Sukavejworakit et al. 2018). When the aim of the $\mathrm{EE}$ is to enrich entrepreneurship awareness, the best approach is to disseminate information through mass media, including online or offline media, seminars and lectures. This has been seen to be successful in targeting target markets in a shot timeframe. When the goal of the EE is to prepare learners with entrepreneurship skills, the best approach is to employ industrial training. In the meantime, if the goal of the EE is to create entrepreneurs, the optimal approach is to use market simulation or to play a role in facilitating experiments. Irrespective of the different methods used to meet a variety of goals, learning institutions have a key role to play in facilitating the transfer of EAs to students (Aries et al. 2020). In the meantime, other (Prabhu et al. 2020) had their own views on the EE. Primarily, these researchers contrast between traditional management education and the EE, seeing the former as an obstacle to the development of entrepreneurial content and qualities. This means that the EE has to be addressed in a distinct way. In order to emphasize the usefulness of the EE, it must be linked to based learning (Anwar, 2016), work-related learning (Tan et al. 2020), entrepreneurship training and experiential learning (Abdullah et al. 2017). Training to start up a new company focuses on learning to combine experience, expertise and skills. In general, EE must be capable of educating learners to understand the goal of a company, an organisation and a partnership between business and the economy and society. More precisely, EE should be capable 
of exchanging skills that may be delivered within the confines of learning institutions, enabling individuals to make new and creative ideas (Bell \& Bell, 2020). Researchers also proposed the adoption of the EE at the early stages of individual schooling (Othman \& Abdullah, 2016). Based on an investigation by Anwar, (2017), the researcher found that EE school students had a strong interest in contemplating setting up their own company after graduation. Meanwhile, in Hong Kong, students have been seen to be increasingly knowledgeable of business and to acquire related personal qualities from exposure to $\mathrm{EE}$ in their secondary schools (Youssef et al. 2021). In view of the promising interaction between the EE and influences linked to the growth of entrepreneurship, multiple nations have begun to implement the EE, which encompasses a comprehensive level of education structures (i.e. universities, colleges and schools) (Qazi et al. 2020).

\section{METHODOLOGY}

The purpose of this study is to measure the influence of experiential learning on the entrepreneurial intention at higher education. To enable the research to measure experiential learning, the researchers used three dimensions as independent factors (empirical learning, Cognitive loading, and Self-efficacy) and on the other hand entrepreneurial intention at higher education as dependent factor. The study was carried out at private universities in Erbil. The researchers employed quantitative research method via adapting questionnaire from academic source and publish it online to gather information from participants. The questionnaire was distributed randomly among 120 academic and administrative staffs of private universities. The participants of the present study were 103 participants from different private universities in Kurdistan region of Iraq.

\section{Conceptual framework}

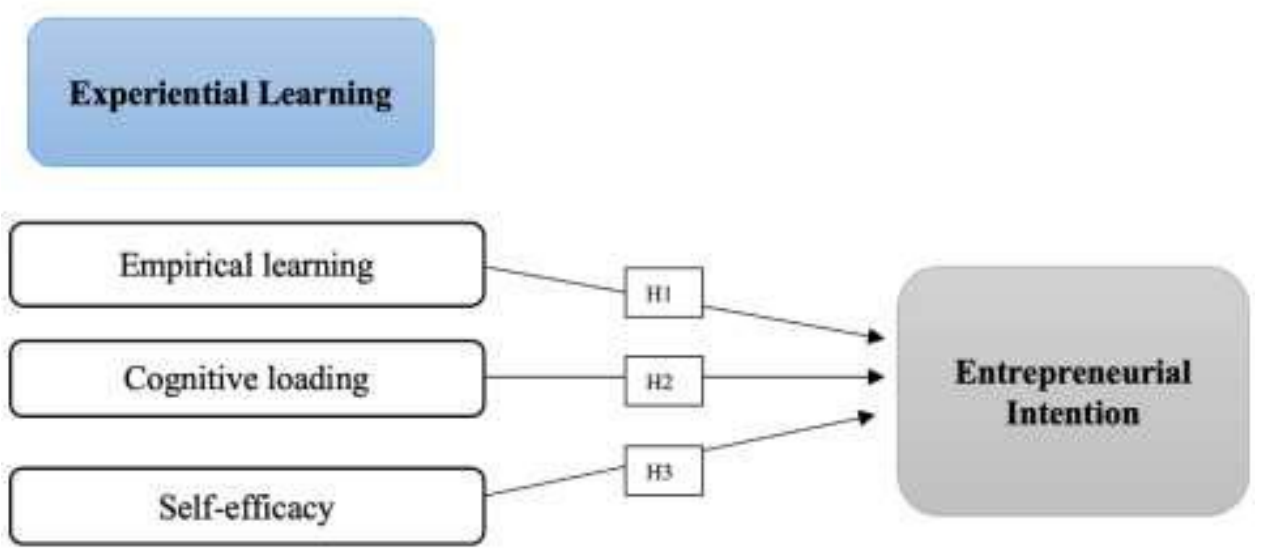

Fig.1: Conceptual Framework

\section{Research Hypotheses}

Hypothesis one: There is a significant relationship between empirical learning as element of experiential learning with entrepreneurial intention.

Hypothesis two: There is a significant relationship between Cognitive loading as element of experiential learning with entrepreneurial intention.

Hypothesis three: There is a significant relationship between Self-efficacy as element of experiential learning with entrepreneurial intention.

\section{Findings}

The current research focused on assessing the impact of social media (empirical learning, Cognitive loading, and Self-efficacy) on entrepreneurial intention. In order to measure social media and its impact on entrepreneurial intention, the researchers set three independent variables as slef-leadership skills, theses variables are (empirical learning, Cognitive loading, and Self-efficacy) on the other hand entrepreneurial intention as dependent variable. The researchers applied simple regression analysis to measure the influence of each independent variable separately on entrepreneurial intention. 
Table.1: KMO and Bartlett Sphericity Test of Self-rating Items

\begin{tabular}{|c|c|c|c|c|c|c|}
\hline \multirow[t]{2}{*}{ No } & \multirow[t]{2}{*}{ Factors } & \multirow[t]{2}{*}{$\mathrm{N}$ of items } & \multirow[t]{2}{*}{ Sample } & \multirow[t]{2}{*}{ KMO } & \multicolumn{2}{|l|}{ Bartlett test } \\
\hline & & & & & Chi-Square & Sig \\
\hline 1 & Empirical learning & 8 & 103 & \multirow{4}{*}{.801} & \multirow{4}{*}{4211.4} & \multirow{4}{*}{.000} \\
\hline 2 & Cognitive loading & 7 & 103 & & & \\
\hline 3 & Self-efficacy & 7 & 103 & & & \\
\hline 4 & Entrepreneurial intention & 8 & 103 & & & \\
\hline
\end{tabular}

As we can see in table (1), the outcome of KMO is .801 which is higher than .001 this indicates that the sample size used for the current study was more than adequate. Furthermore, the result of Chi-Square is 4211.4.3 with the significant level .000.

Table 2: Factor Analysis

\begin{tabular}{|c|c|c|c|c|c|c|}
\hline \multirow[t]{2}{*}{ No } & \multirow[t]{2}{*}{ Components } & \multirow[t]{2}{*}{$\begin{array}{l}\text { Number of } \\
\text { Items }\end{array}$} & \multirow[t]{2}{*}{$\mathbf{N}$} & \multirow[t]{2}{*}{ Eigenvalue } & \multicolumn{2}{|c|}{$\begin{array}{c}\text { Rotation Sums of Squared } \\
\text { Loadings }\end{array}$} \\
\hline & & & & & $\begin{array}{c}\% \text { of } \\
\text { Variance }\end{array}$ & Cumulative \\
\hline 1 & Empirical learning & 8 & 103 & 1.2891 & 16.021 & 11.201 \\
\hline 2 & Cognitive loading & 7 & 103 & 5.021 & 12.233 & 21.225 \\
\hline 3 & Self-efficacy & 7 & 103 & 1.933 & 12.252 & 17.322 \\
\hline 4 & Entrepreneurial intention & 8 & 103 & 1.52 & 12.363 & 18.222 \\
\hline
\end{tabular}

Table (2) demonstrates three independent variables social media (Empirical learning, Cognitive loading, and Selfefficacy) and a dependent variable (Entrepreneurial intention). As for empirical learning as first element of social media, which had eight item explained $16.021 \%$ of the total variance. As for Cognitive loadingas second element of social media, which had seven items explained $12.233 \%$ of the total variance. As for Co Self-efficacyas third element of social media, which had seven items explained $12.252 \%$ of the total variance. And finally, as for Entrepreneurial intention as dependent variable, which had eight items explained $12.363 \%$ of the total variance.

Table 3: Reliability Test

\begin{tabular}{|c|c|c|c|}
\hline \multicolumn{3}{|c|}{ Reliability Statistics } \\
\hline Factor & $\mathbf{N}$ & Cronbach's Alpha & N of Items \\
\hline Empirical learning & 103 & .739 & 7 \\
\hline Cognitive loading & 103 & .792 & 7 \\
\hline Self-efficacy & 103 & .787 & 8 \\
\hline Entrepreneurial intention & 103 & .771 & 8 \\
\hline
\end{tabular}

As seen in table (3), the reliability analysis for 30 items used to measure the influence social media (Empirical learning, Cognitive loading, and Self-efficacy) to measure the influence on Entrepreneurial intention. The above 30 questions were distributed as follow; eight items for empirical learning, seven items for cognitive loading, seven items for self-efficacy, and eight items for Entrepreneurial intention. The researchers applied reliability analysis to find out the reliability for each factor, the findings revealed as follow: as for experiential learning was found the Alpha to be .739 for eight questions which indicated that all eight questions used to measure experiential learning were reliable for the current study, as for cognitive loading was found the Alpha to be .792 for seven questions which indicated that all seven questions used to measure cognitive loading were reliable for the current study, as for self- 
efficacy was found the Alpha to be .787 for seven questions which indicated that all seven questions used to measure Self-efficacy were reliable for the current study, and as for entrepreneurial intention was found the Alpha to be .771 for eight questions which indicated that all eight questions used to measure entrepreneurial intention were reliable for the current study.

First Research Hypothesis

\section{Empirical learning}

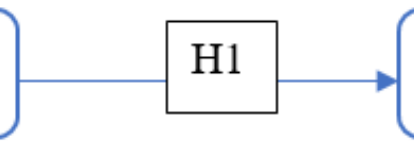

Entrepreneurial intention

Hypothesis one: There is a significant relationship between empirical learning as element of experiential learning with entrepreneurial intention.

Table 4: Correlation analysis

\begin{tabular}{|l|l|c|c|}
\hline \multicolumn{3}{|c|}{ Correlations } \\
\hline Variables & Pearson Correlation & Entrepreneurial Intention & Empirical Learning \\
\hline \multirow{3}{*}{$\begin{array}{l}\text { Entrepreneurial } \\
\text { Intention }\end{array}$} & Pearson Correlation & 1 & $.674^{* *}$ \\
\cline { 2 - 4 } & Sig. (2-tailed) & & .000 \\
\cline { 2 - 4 } & $\mathrm{N}$ & 103 & 103 \\
\hline \multirow{2}{*}{$\begin{array}{l}\text { Empirical } \\
\text { Learning }\end{array}$} & Pearson Correlation & $.674^{* *}$ & 1 \\
\cline { 2 - 4 } & Sig. (2-tailed) & .000 & 103 \\
\cline { 2 - 4 } & $\mathrm{N}$ & 103 & \\
\hline$* *$ Correlation is significant at the 0.01 level (2-tailed). & & \\
\hline
\end{tabular}

As it can be seen in table (4), the correlation analysis between empirical learnings to measure its influence on entrepreneurial intention. The finding revealed that the value of Pearson correlation $\left(r=.674^{* *}, p<0.01\right)$, this indicated that there is positive and strong correlation between empirical Learningas self-leadership skill and entrepreneurial intention.

Table 5-Model Summary

\begin{tabular}{|l|r|r|r|r|}
\hline \multicolumn{7}{|c|}{ Model Summary } \\
\hline Model & R & R Square & Adjusted R Square & Std. Error of the Estimate \\
\hline 1 & .617 & .602 & .578 & .21471 \\
\hline
\end{tabular}

Regression analysis is the study of interactions between variables. $\mathrm{Y}=\mathrm{f}(\mathrm{x} 1, \mathrm{x} 2, \ldots \mathrm{Xc})$ The aim of regression analysis is to determine how $Y$ can affect and alter $X$. The Affective Learningapproach is treated as an independent variable in this section, while entrepreneurial intention is treated as a dependent variable. The volatility of a comparative advantage will be used to calculate its total difference. The variations are determined by calculating the sum of the squares of the expected competitive advantage values by the overall mean divided by the number of participants. After dividing the variance by the overall variance of comparative benefit, the researcher discovered the sum or percentage of total differences or variances that are compensated for using regression analysis. The number can range from 0 to 1 and is defined by $\mathrm{R}$ Square. The value of $\mathrm{R}$ square $=.578$ as seen in Table (5), indicating that 57 percent of total variation has been clarified. 
Table 6-ANOVA

\begin{tabular}{|c|c|c|c|c|c|c|}
\hline \multicolumn{7}{|c|}{ ANOVA } \\
\hline \multicolumn{2}{|c|}{ Model } & Sum of Squares & df & Mean Square & $\mathrm{F}$ & Sig. \\
\hline \multirow[t]{3}{*}{1} & Regression & 104.128 & 1 & 131.211 & 214.174 & $.000^{\mathrm{b}}$ \\
\hline & Residual & 311.214 & 528 & .028 & & \\
\hline & Total & 415.342 & 529 & & & \\
\hline \multicolumn{7}{|c|}{ a. Dependent Variable: Entrepreneurial Intention } \\
\hline
\end{tabular}

Table (6) shows that the $\mathrm{F}$ value for experiential Learning as an independent variable $=214.174$, indicating that there is a significant relationship between experiential learning and entrepreneurial intention $(214.174,>1)$.

Table 7-Coefficients Analysis

\begin{tabular}{|c|c|c|c|c|c|c|}
\hline \multicolumn{7}{|c|}{ Coefficients } \\
\hline \multirow{2}{*}{\multicolumn{2}{|c|}{ Model }} & \multicolumn{2}{|c|}{$\begin{array}{l}\text { Unstandardized } \\
\text { Coefficients }\end{array}$} & \multirow{2}{*}{$\begin{array}{c}\begin{array}{c}\text { Standardized } \\
\text { Coefficients }\end{array} \\
\text { Beta }\end{array}$} & \multirow[t]{2}{*}{$\mathrm{t}$} & \multirow[t]{2}{*}{ Sig. } \\
\hline & & B & Std. Error & & & \\
\hline \multirow[t]{2}{*}{1} & (Constant) & .144 & .027 & & 2.591 & .000 \\
\hline & $\begin{array}{l}\text { Empirical } \\
\text { learning }\end{array}$ & .631 & .019 & .634 & 19.391 & .000 \\
\hline
\end{tabular}

Table (7) shows the implications of the first hypothesis: Empirical Learning strongly predicts entrepreneurial intention (Beta is weight .634, p.001), implying that empirical Learning would have a clear beneficial relationship with entrepreneurial intention.

\section{Second Research Hypothesis}

\section{Cognitive loading}

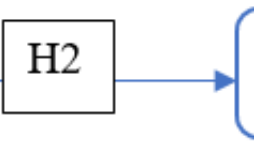

\section{Entrepreneurial intention}

Hypothesis two: There is a significant relationship between cognitive loading as element of experiential learning with entrepreneurial intention.

Table 8: Correlation analysis

\begin{tabular}{|l|l|c|c|}
\hline \multicolumn{3}{|c|}{ Correlations } \\
\hline Variables & Pearson Correlation & Entrepreneurial intention & Cognitive loading \\
\hline Entrepreneurial intention & Pearson Correlation & 1 & $.641^{* *}$ \\
\cline { 2 - 4 } & Sig. (2-tailed) & & .000 \\
\cline { 2 - 4 } & $\mathrm{N}$ & 103 & 103 \\
\hline Cognitive loading & Pearson Correlation & $.641^{* *}$ & 1 \\
\cline { 2 - 4 } & Sig. (2-tailed) & .000 & 103 \\
\cline { 2 - 4 } & $\mathrm{N}$ & 103 & \\
\hline$* *$. Correlation is significant at the 0.01 level (2-tailed). & & \\
\hline
\end{tabular}

As it can be seen in table (8), the correlation analysis between cognitive loading as an experiential learning to measure its influence on entrepreneurial intention in private hospitals in Kurdistan region of Iraq. The finding revealed 
that the value of Pearson correlation $\left(\mathrm{r}=.641^{* *}, \mathrm{p}<0.01\right)$, this indicated that there is positive and strong correlation between cognitive loading as an experiential learning $\mathrm{t}$ and entrepreneurial intention.

Table 9-Model Summary

\begin{tabular}{|l|r|r|r|r|}
\hline \multicolumn{7}{|c|}{ Model Summary } \\
\hline Model & $\mathrm{R}$ & R Square & Adjusted R Square & Std. Error of the Estimate \\
\hline 1 & .699 & .674 & .611 & .17525 \\
\hline \multicolumn{2}{|l|}{ a. Predictors: (Constant), Cognitive loading } \\
\hline
\end{tabular}

Regression analysis is the study of interactions between variables. $\mathrm{Y}=\mathrm{f}(\mathrm{x} 1, \mathrm{x} 2, \ldots \mathrm{Xc})$ The aim of regression analysis is to determine how $\mathrm{Y}$ can affect and alter $\mathrm{X}$. The Cognitive loadingapproach is treated as an independent variable in this section, while entrepreneurial intention is treated as a dependent variable. The volatility of a comparative advantage will be used to calculate its total difference. The variations are determined by calculating the sum of the squares of the expected competitive advantage values by the overall mean divided by the number of participants. After dividing the variance by the overall variance of comparative benefit, the researcher discovered the sum or percentage of total differences or variances that are compensated for using regression analysis. The number can range from 0 to 1 and is defined by $\mathrm{R}$ Square. The value of $\mathrm{R}$ square $=.674$ as seen in Table (9), indicating that 67 percent of total variation has been clarified.

Table 10-ANOVA

\begin{tabular}{|c|c|c|c|c|c|c|}
\hline \multicolumn{7}{|c|}{ ANOVA } \\
\hline \multicolumn{2}{|c|}{ Model } & Sum of Squares & df & Mean Square & $\mathrm{F}$ & Sig. \\
\hline \multirow[t]{3}{*}{1} & Regression & 19.521 & 1 & 111.21 & 17.252 & $.000^{\mathrm{b}}$ \\
\hline & Residual & 17.554 & 399 & .036 & & \\
\hline & Total & 37.075 & 400 & & & \\
\hline \multicolumn{7}{|c|}{ a. Dependent Variable: Entrepreneurial intention } \\
\hline \multicolumn{7}{|c|}{ b. Predictors: (Constant), Cognitive loading } \\
\hline
\end{tabular}

Table (10) shows that the $\mathrm{F}$ value for Cognitive loadingas an independent variable $=17.252$, indicating that there is a significant relationship between Cognitive loadingand entrepreneurial intention (17.252>1).

Table 11-Coefficients Analysis

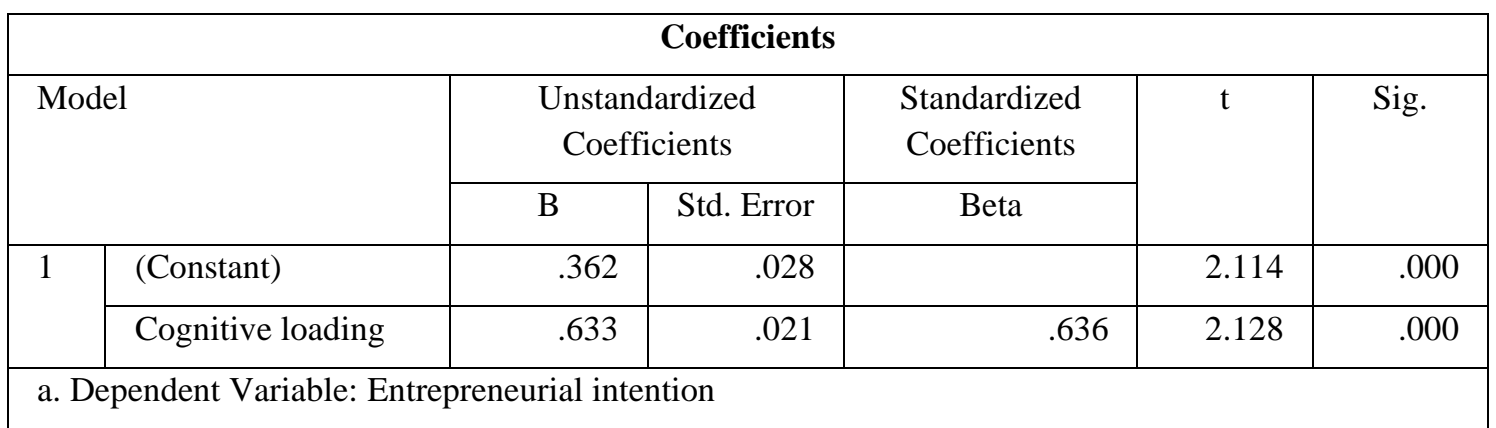

Table (11) shows the implications of the second hypothesis: Cognitive loading strongly predicts entrepreneurial intention (Beta is weight .636, p.001), implying that cognitive loading would have a clear beneficial relationship with entrepreneurial intention. 


\section{Third Research Hypothesis}

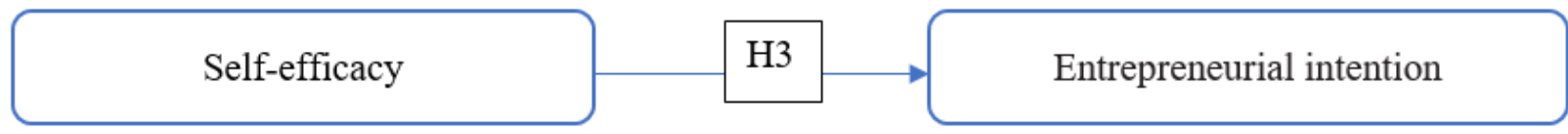

Hypothesis three: There is a significant relationship between Self-efficacy as element of experiential learning with entrepreneurial intention.

Table 12: Correlation analysis

\begin{tabular}{|l|l|c|c|}
\hline \multirow{2}{*}{ Variables } & Pearson Correlation & $\begin{array}{c}\text { Entrepreneurial } \\
\text { intention }\end{array}$ & Self-efficacy \\
\hline \multirow{3}{*}{$\begin{array}{l}\text { Entrepreneurial } \\
\text { intention }\end{array}$} & Pearson Correlation & 1 & $.621^{* *}$ \\
\cline { 2 - 4 } & Sig. (2-tailed) & & .000 \\
\cline { 2 - 4 } & $\mathrm{N}$ & $.621^{* *}$ & 103 \\
\hline \multirow{3}{*}{ Self-efficacy } & Pearson Correlation & .000 & 103 \\
\cline { 2 - 4 } & Sig. (2-tailed) & 103 & 1 \\
\cline { 2 - 4 } & $\mathrm{N}$ & & \\
\hline \multirow{2}{*}{$* *$ Correlation is significant at the 0.01 level (2-tailed). }
\end{tabular}

As it can be seen in table (12), the correlation analysis between Self-efficacy as an experiential learning to measure its influence on entrepreneurial intention in private hospitals in Kurdistan region of Iraq. The finding revealed that the value of Pearson correlation $\left(\mathrm{r}=.621^{* *}, \mathrm{p}<0.01\right)$, this indicated that there is positive and strong correlation between Self-efficacy as an experiential learning and entrepreneurial intention.

Table 13-Model Summary

\begin{tabular}{|l|r|r|r|r|}
\hline \multicolumn{7}{|c|}{ Model Summary } \\
\hline Model & R & R Square & Adjusted R Square & Std. Error of the Estimate \\
\hline 1 & .591 & .539 & .581 & .1366 \\
\hline \multicolumn{2}{|l|}{ a. Predictors: (Constant), Self-efficacy } \\
\hline
\end{tabular}

Regression analysis is the study of interactions between variables. $\mathrm{Y}=\mathrm{f}(\mathrm{x} 1, \mathrm{x} 2, \ldots \mathrm{Xc})$ The aim of regression analysis is to determine how $\mathrm{Y}$ can affect and alter $\mathrm{X}$. The Selfefficacyis treated as an independent variable in this section, while entrepreneurial intention is treated as a dependent variable. The volatility of a comparative advantage will be used to calculate its total difference. The variations are determined by calculating the sum of the squares of the expected competitive advantage values by the overall mean divided by the number of participants. After dividing the variance by the overall variance of comparative benefit, the researcher discovered the sum or percentage of total differences or variances that are compensated for using regression analysis. The number can range from 0 to 1 and is defined by $\mathrm{R}$ Square. The value of $\mathrm{R}$ square $=.539$ seen in Table (13), indicating that 53 percent of total variation has been clarified.

Table 14-ANOVA

\begin{tabular}{|l|l|c|c|c|c|c|}
\hline \multicolumn{7}{|c|}{ ANOVA } \\
\hline \multicolumn{2}{|c|}{ Model } & Sum of Squares & df & Mean Square & F & Sig. \\
\hline 1 & Regression & 101.21 & 1 & 10.363 & 17.522 & $.000^{\mathrm{b}}$ \\
\hline
\end{tabular}




\begin{tabular}{|l|l|r|r|r|l|l|}
\hline & Residual & 14.252 & 458 & .091 & & \\
\cline { 2 - 6 } & Total & 115.462 & 459 & & & \\
\hline
\end{tabular}

Table (14) shows that the $\mathrm{F}$ value for floatationas an independent variable $=17.522$, indicating that there is a significant relationship between Self-efficacyand entrepreneurial intention (17.522>1).

Table 15-Coefficients Analysis

\begin{tabular}{|c|c|c|c|c|c|c|}
\hline \multicolumn{7}{|c|}{ Coefficients } \\
\hline \multirow{2}{*}{\multicolumn{2}{|c|}{ Model }} & \multicolumn{2}{|c|}{$\begin{array}{l}\text { Unstandardized } \\
\text { Coefficients }\end{array}$} & \multirow{3}{*}{$\begin{array}{c}\begin{array}{c}\text { Standardized } \\
\text { Coefficients }\end{array} \\
\text { Beta }\end{array}$} & \multirow[t]{2}{*}{$\mathrm{t}$} & \multirow[t]{2}{*}{ Sig. } \\
\hline & & B & Std. Error & & & \\
\hline \multirow[t]{2}{*}{1} & (Constant) & .124 & .031 & & 2.114 & .000 \\
\hline & Self-efficacy & .639 & .028 & .644 & 19.227 & .000 \\
\hline
\end{tabular}

Table (1415 shows the implications of the third hypothesis: Self-efficacystrongly predicts entrepreneurial intention (Beta is weight .644, p.001), implying that Floatationwould have a clear beneficial relationship with entrepreneurial intention.

\section{CONCLUSION}

This study contributes to our understanding of social entrepreneurship education by providing the first quantitative pre/post study of how experiential social entrepreneurship education affects social entrepreneurial intentions and their antecedents. It shows that such education can affect intentions, social-entrepreneurial selfefficacy, and perceived social support. The results are robust, as evidenced by the second sample, which comes to the same conclusions as the first sample, despite drawing on a much more diverse sample in terms of age, culture, and educational background and also using a different delivery mechanism (online education rather than classroom teaching). Our aptitude to develop social entrepreneurs through business school education depends on our evolving understanding of how business school education can impact the intentions and behavior of students. In this light, it is to be hoped that future research will carry out more intervention studies like this one. Moreover, replication in different contexts would be a valuable step in further addressing the underlying question of this paper. The study developed three research hypotheses, the findings revealed that, as for the first research hypothesis found that an empirical Learning strongly predicts entrepreneurial intention, implying that empirical Learning would have a clear beneficial relationship with entrepreneurial intention. As for the second research hypothesis, it was found that a cognitive loading strongly predicts entrepreneurial intention, implying that cognitive loading would have a clear beneficial relationship with entrepreneurial intention, and lastly as for the third research hypothesis, it was found that self-efficacystrongly predicts entrepreneurial intention, implying that Floatationwould have a clear beneficial relationship with entrepreneurial intention.

\section{REFERENCES}

[1] Khan, S., \& Abdullah, N. N. (2019). The impact of staff training and development on teachers' productivity. Economics, Management and Sustainability, 4(1).

[2] Mueller, S. (2011). Increasing entrepreneurial intention: effective entrepreneurship course characteristics. International Journal of Entrepreneurship and Small Business, 13(1), 55-74.

[3] Sukavejworakit, K., Promsiri, T., \& Virasa, T. (2018). OETEL: An innovative teaching model for entrepreneurship education. Journal of Entrepreneurship Education, 21(2), 111.

[4] Anwar, K. (2017). analyzing the conceptual model of service quality and its relationship with guests'satisfaction: a study of hotels in erbil. The International Journal of Accounting and Business Society, 25(2), 1-16.

[5] Ozaralli, N., \& Rivenburgh, N. K. (2016). Entrepreneurial intention: antecedents to entrepreneurial behavior in the USA and Turkey. Journal of Global Entrepreneurship Research, 6(1), 1-32.

[6] Sukavejworakit, K., Promsiri, T., \& Virasa, T. (2018). Increasing entrepreneurial intention with the application of experiential learning theory: An innovative learning method 
and empirical test. Asia-Pacific Social Science Review, 18(2), 1-15.

[7] Aries, A., Vional, V., Saraswati, L., Wijaya, L., \& Ikhsan, R. (2020). Gamification in learning process and its impact on entrepreneurial intention. Management Science Letters, 10(4), 763-768.

[8] Prabhu, M., Nambirajan, T., \& Abdullah, N. N. (2020). Analytical review on competitive priorities for operations under manufacturing firms. Journal of Industrial Engineering and Management, 13(1), 38-55.

[9] Anwar, K. (2016). Comparison between cost leadership and differentiation strategy in agricultural businesses. Custos $E$ Agronegocio on Line, 12(2), 212-231.

[10] Tan, L. P., Le, A. N. H., \& Xuan, L. P. (2020). A systematic literature review on social entrepreneurial intention. Journal of Social Entrepreneurship, 11(3), 241-256.

[11] Abdullah, M. S., Toycan, M., \& Anwar, K. (2017). The cost readiness of implementing e-learning. CUSTOS E AGRONEGOCIO ON LINE, 13(2), 156-175.

[12] Bell, R., \& Bell, H. (2020). Applying educational theory to develop a framework to support the delivery of experiential entrepreneurship education. Journal of Small Business and Enterprise Development.

[13] Anwar, K., \& Balcioglu, H. (2016). The relationship between transformational leadership characteristics and effectiveness: A case study of construction companies in Erbil. International Journal of Science Technology and Management, 5(2), 250-256.

[14] Othman, M., \& Abdullah, N. N. (2016). The conceptual assessment of Malaysian entrepreneurship environment and EO economic contribution. Othman, M., Saud, MB, Mat Isa, MA, \& Abdullah, NN (2015). The Conceptual Assessment of Malaysian Entrepreneurship Environment and EO Economic Contribution. Journal of Resources Development and Management, 20, 15-20.

[15] Anwar, K. (2017). The Role of Effective Leadership in Crisis Management: Study of Private Companies in Kurdistan. Qalaai Zanist Scientific Journal, 2(4), 326-338.

[16] Youssef, A. B., Boubaker, S., Dedaj, B., \& CarabreguVokshi, M. (2021). Digitalization of the economy and entrepreneurship intention. Technological Forecasting and Social Change, 164, 120043.

[17] Abdullah, N. N., \& Abdul Rahman, M. (2015). The use of deliberative democracy in public policy making process. Abdullah, NN \& Rahman, MFA (2015). The Use of Deliberative Democracy in Public Policy Making Process. Public Policy and Administration Research, 5(3), 221-229.

[18] Qazi, W., Qureshi, J. A., Raza, S. A., Khan, K. A., \& Qureshi, M. A. (2020). Impact of personality traits and university green entrepreneurial support on students' green entrepreneurial intentions: the moderating role of environmental values. Journal of Applied Research in Higher Education.

[19] Hameed, A. A., \& Anwar, K. (2018). Analyzing the Relationship between Intellectual Capital and Organizational Performance: A Study of Selected Private Banks in Kurdistan. International Journal of Social Sciences \& Educational Studies, 4(4), 39.
[20] Anwar, K., \& Ghafoor, C. (2017). Knowledge management and organizational performance: A study of private universities in Kurdistan. International Journal of Social Sciences \& Educational Studies, 4(2), 53.

[21] Prabhu, M., Abdullah, N. N., \& Madan Mohan, G. (2019). An Empirical Study on the Satisfaction Level of National and International Tourists towards Natural Attractions in Kurdistan. African Journal of Hospitality, Tourism and Leisure, 8(2), 1-8.

[22] Anwar, K. (2017). FACTORS AFFECTING STOCK EXCHANGE INVESTMENT IN KURDISTAN. The International Journal of Accounting and Business Society, 25(1), 32-37.

[23] Tierno, L. G., Pérez-Macías, N., \& Medina-Molina, C. (2020). Visual Thinking Boosting Spanish Higher Education Students' Entrepreneurial Intentions. Journal of the Knowledge Economy, 1-17.

[24] Bazan, C., Gaultois, H., Shaikh, A., Gillespie, K., Frederick, S., Amjad, A., ... \& Belal, N. (2020). A systematic literature review of the influence of the university's environment and support system on the precursors of social entrepreneurial intention of students. Journal of Innovation and Entrepreneurship, 9(1), 4.

[25] Anwar, K., \& Qadir, G. H. A Study of the Relationship between Work Engagement and Job Satisfaction in Private Companies in Kurdistan. International Journal of Advanced Engineering, Management and Science, 3(12), 239944.

[26] Anwar, G., \& Shukur, I. (2015). The Impact of Training and Development on Job Satisfaction: A Case Study of Private Banks in Erbil. International Journal of Social Sciences \& Educational Studies, 2(1), 65.

[27] Anjum, T., Ramani Bai, V., \& Nazar, N. (2020). Mediating role of attitudes to enhance the creativity disposition towards entrepreneurial intention. International Journal of Psychosocial Rehabilitation, 24(3), 542-553.

[28] Yi, G. (2020). From green entrepreneurial intentions to green entrepreneurial behaviors: the role of university entrepreneurial support and external institutional support. International Entrepreneurship and Management Journal, 1-17.

[29] Anwar, G., \& Surarchith, N. K. (2015). Factors Affecting Shoppers' Behavior in Erbil, Kurdistan-Iraq. International Journal of Social Sciences \& Educational Studies, 1(4), 10.

[30] Anwar, G., \& Shukur, I. (2015). The Impact of Service Quality Dimensions on Students' Satisfaction. International Journal of Social Sciences \& Educational Studies, 76.

[31] Anwar, K. (2017). Leading Construction Project Teams: The Effectiveness of Transformational Leadership in Dynamic Work Environments in Kurdistan. International Journal of Advanced Engineering, Management and Science, 3(10), 239925.

[32] Abdullah, N. N., \& Othman, M. B. (2019). Examining the effects of intellectual capital on the performance of Malaysian food and beverage small and medium-sized enterprises. Technology (IJCIET), 10(2), 135-143.

[33] Anwar, G., \& Shukur, I. (2015). the impact of recruitment and selection on job satisfaction: Evidence from private 
school in Erbil. International Journal of Social Sciences \& Educational Studies, 1(3), 4-13.

[34] Prabhu, M., Abdullah, N. N., Ahmed, R. R., Nambirajan, T., \& Pandiyan, S. (2020). Segmenting the manufacturing industries and measuring the performance: Using intervalvalued triangular fuzzy TOPSIS method. Complex \& Intelligent Systems, 6, 591-606.

[35] Anwar, G., \& Abd Zebari, B. (2015). The Relationship between Employee Engagement and Corporate Social Responsibility: A Case Study of Car Dealership in Erbil, Kurdistan. International Journal of Social Sciences \& Educational Studies, 2(2), 45.

[36] Dijinira, R., José, M. M., \& AR, D. F. (2020). Entepreneurship Education and Entrepreneurial Intention: the Case of Portugal. Экономика региона, 16(1).

[37] Abdullah, N. N., \& Othman, M. (2016). The contribution of human capital investment in the growth of East Asian economy-A literature review. Journal of Economic and Business Research, 22(1), 190-203.

[38] Anwar, G., \& Shukur, I. (2015). Job satisfaction and employee turnover intention: A case study of private hospital in Erbil. International Journal of Social Sciences \& Educational Studies, 2(1), 73.

[39] Dijinira, R., José, M. M., \& AR, D. F. (2020). Entepreneurship Education and Entrepreneurial Intention: the Case of Portugal. Экономика региона, 16(1).

[40] Zulfiqar, S., Al-reshidi, H. A., Al Moteri, M. A., Feroz, H. M. B., Yahya, N., \& Al-Rahmi, W. M. (2021). Understanding and Predicting Students' Entrepreneurial Intention through Business Simulation Games: A Perspective of COVID-19. Sustainability, 13(4), 1838.

[41] Fayolle, A., Lamine, W., Mian, S., \& Phan, P. (2020). Effective models of science, technology and engineering entrepreneurship education: current and future research. The Journal of Technology Transfer, 1-11.

[42] Naz, S., Li, C., Zaman, U., \& Rafiq, M. (2020). Linking Proactive Personality and Entrepreneurial Intentions: A Serial Mediation Model Involving Broader and Specific Self-Efficacy. Journal of Open Innovation: Technology, Market, and Complexity, 6(4), 166. 